J. GENG* , Y. ZHANG, Q. GAO, K. NEUMANN, H. DONG, H. PORTER, M. POTTER, H. REN, D. ARGYLE, M. BRADLEY* (UNIVERSITY OF EDINBURGH, UK AND THE SHENZHEN INSTITUTE OF ADVANCED TECHNOLOGY, P. R. OF CHINA)

Switching on Prodrugs Using Radiotherapy

Nat. Chem. 2021, 13, 805-810, DOI: 10.1038/s41557-021-00711-4.

\title{
X-ray Irradiation Promoted Activation of Prodrugs
}

\section{Synthesis of prodrug:}<smiles>N#Cc1c(F)c(F)c(CO)c(F)c1F</smiles><smiles>O=C(Cl)Oc1ccc([N+](=O)[O-])cc1</smiles>

1. A, py

2. doxorubicin, $\mathrm{Et}_{3} \mathrm{~N}$

$81 \%$ over 2 steps

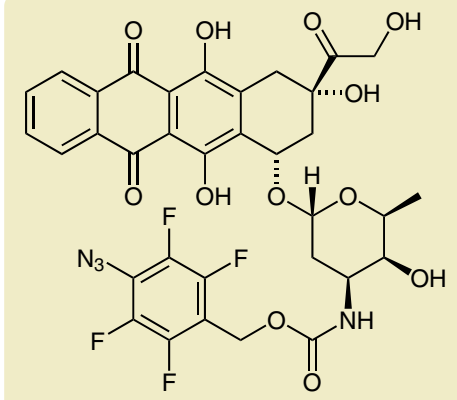

caged doxorubicin prodrug

Prodrug activation by X-ray irradiation:<smiles>CC1OC(CCO)(OC2C[C@](O)(C(=O)CO)Cc3c(O)c4c(c(O)c32)C(=O)c2ccccc2C4=O)C[C@@H](NC(=O)OCc2c(F)c(F)c(N=[N+]=[N-])c(F)c2F)C(O)C1O</smiles>

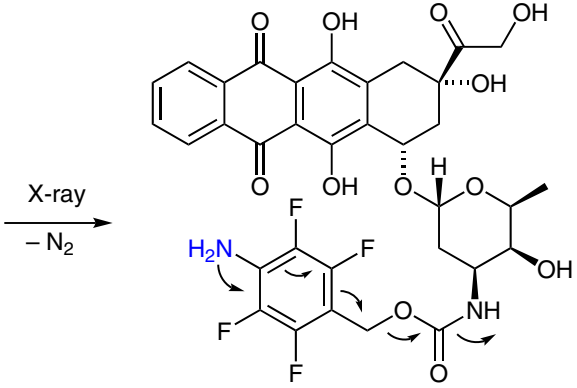

inactive prodrug<smiles>Nc1c(F)c(F)c(CO)c(F)c1F</smiles>

$+$<smiles>CC1OC(O[C@H]2C[C@@](O)(C(=O)CO)Cc3c(O)c4c(c(O)c32)C(=O)c2ccccc2C4=O)C[C@H](N)C1O</smiles>

decarboxylation

Significance: Activating an anticancer prodrug with clinical doses of ionizing radiation could enable localized release of a drug at the tumor site and potentially eliminate the global systemic toxicity of conventional chemo-radiotherapy. In a tumorbearing mice model, the combination of caged prodrug and X-ray treatment not only inhibited tumor growth but also reduced doxorubicin-induced heart toxicity.
Comment: The caged doxorubicin prodrug was synthesized in two steps, by following a reported procedure (Bioconjugate Chem. 2018, 29, 324). Decaging of doxorubicin was achieved using X-ray irradiation (from 0 to $60 \mathrm{~Gy}$ ) through radical reduction of the tetrafluorophenyl azide followed by 1,6-self-immolation linker cleavage.

Chemistry in

Medicine and

Biology

Key words

cancer prodrugs

radiotherapy

$\mathrm{X}$-ray irradiation

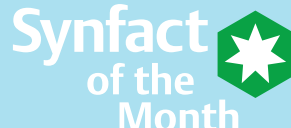

